Decision Making in Social Work 


\title{
Decision Making in Social Work
}

\author{
Terence O'Sullivan
}




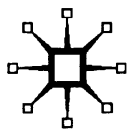

All rights reserved. No reproduction, copy or transmission of this publication may be made without written permission.

No paragraph of this publication may be reproduced, copied or transmitted save with written permission or in accordance with the provisions of the Copyright, Designs and Patents Act 1988, or under the terms of any licence permitting limited copying issued by the Copyright Licensing Agency, 90 Tottenham Court Road, London W1P OLP.

Any person who does any unauthorised act in relation to this publication may be liable to criminal prosecution and civil claims for damages.

The author has asserted his right to be identified as the author of this work in accordance with the Copyright, Designs and Patents Act 1988.

Published by

PALGRAVE

Houndmills, Basingstoke, Hampshire RG21 6XS and 175 Fifth Avenue, New York, N. Y. 10010

Companies and representatives throughout the world

PALGRAVE is the new global academic imprint of St. Martin's Press LLC Scholarly and Reference Division and Palgrave Publishers Ltd (formerly Macmillan Press Ltd).

ISBN 978-0-333-68481-8 DOI 10.1007/978-1-349-14369-6

This book is printed on paper suitable for recycling and made from fully managed and sustained forest sources.

A catalogue record for this book is available from the British Library.

$\begin{array}{lllllll}10 & 9 & 8 & 7 & 6 & 5 & 4\end{array}$

$\begin{array}{lllll}09 & 08 & 07 & 06 & 05\end{array}$

Copy-edited and typeset by Povey-Edmondson Tavistock and Rochdale, England 
To Bryony, Joseph, Alice and Ryan 


\section{Contents}

List of Figures ix

Acknowledgements $\quad \mathrm{x}$

Introduction - xi

1 Making Decisions 1

Why focus on decision making? $\quad 2$

What has prevented a clear focus on decision making? 6

What does decision making in social work involve? 10

$\begin{array}{ll}\text { What is sound decision making? } & 16\end{array}$

$\begin{array}{ll}\text { Chapter summary and key points } & 21\end{array}$

2 Decision Making Contexts 23

$\begin{array}{ll}\text { The aim of social work } & 24\end{array}$

$\begin{array}{ll}\text { The nature of society } & 26\end{array}$

$\begin{array}{ll}\text { The relevant legal requirements } & 29\end{array}$

The relevant policy decisions $\quad 32$

$\begin{array}{ll}\text { The nature of the agency } & 35\end{array}$

$\begin{array}{ll}\text { The work of other agencies } & 39\end{array}$

Chapter summary and key points 41

3 Involving the Client 43

Who is the client? 44

What level of involvement? 45

Limits on the level of involvement $\quad 50$

Issues in client involvement $\quad 54$

How is the client to become empowered? 59

$\begin{array}{ll}\text { Chapter summary and key points } & 62\end{array}$

4 Stakeholders Meeting Together $\quad 63$

Who needs to meet together? 64

Issues of power between stakeholders $\quad 67$

Potential benefits of meeting together $\quad 71$

Achieving the potential benefits of meeting together $\quad 74$ 
$\begin{array}{ll}\text { Seeking a consensus } & 79\end{array}$

Different ways of reaching a decision $\quad 81$

$\begin{array}{ll}\text { Chapter summary and key points } & 84\end{array}$

5 Thought and Emotion in Decision Making 85

Two ways of thinking $\quad 85$

The impact of emotions $\quad 92$

Janis and Mann's conflict theory 98

$\begin{array}{lr}\text { Chapter summary and key points } & 102\end{array}$

6 Framing the Decision Situation 103

A picture of the situation $\quad 104$

Decision goals 111

A set of options $\quad 112$

Distortions in the decision frame 116

$\begin{array}{ll}\text { Chapter summary and key points } & 126\end{array}$

7 Choice of Options $\quad 127$

$\begin{array}{lr}\text { The possible outcomes of the options } & 129\end{array}$

Assessment of risk 139

Options as right or wrong 146

The emotional charge of an option 149

Chapter summary and key points $\quad 152$

8 Evaluating Decisions $\quad 153$

Evaluating the making of a decision $\quad 154$

Evaluating decision implementation $\quad 160$

Evaluating decision outcome $\quad 162$

Decision making and decision outcome $\quad 167$

$\begin{array}{ll}\text { Chapter summary and key points } & 170\end{array}$

9 Conclusions 171

$\begin{array}{ll}\text { Bibliography } & 177\end{array}$

Author Index 188

Subject Index 192 


\section{List of Figures}

1.1 Decision chains in social work

1.2 A decision making framework for professional social work

5.1 The use of intuition and analysis in social work

5.2 Janis and Mann's four basic questions

5.3 Four types of impaired information processing

6.1 How factors are used to construct a mental picture of the decision situation

7.1 A simple balance sheet

7.2 A balance sheet using evaluative dimensions 132

7.3 A decision tree

7.4 A strengths/hazards analysis

7.5 The reliability of risk assessment

8.1 The relationship between decision making and decision outcome 


\section{Acknowledgements}

I would like to thank Tom Strickland, Leonne Griggs and Marie Ramsden for their encouraging comments on an early draft of the book and Norma Baldwin for valuable suggestions on ways in which the book could be more clearly focused on practice. Particular thanks is due to Robert Adams who gave me critical feedback at all stages, from the very beginning to the final draft and for his generous support and guidance throughout; to Tony Petch for his comments on the first two chapters; to the staff and students of the University of Lincolnshire and Humberside who over the years have participated in the unit of the same title and, often unknowingly, have helped in the generation of the ideas contained within the book. Last and not least the anonymous Macmillan reviewers whose comments promoted the book's development. Although a number of people have contributed to the book's improvement, the responsibility for its content is mine alone.

Terence O’Sullivan 


\section{Introduction}

When a child is killed by his or her parents, a passer-by murdered by a mentally disordered person or the dead body of an older person has lain undetected in their dingy flat for weeks, the social workers involved are often accused of errors of judgement or incompetence. Sometimes this criticism may be warranted, but often it is unfounded, appearing to fulfil a need to hold somebody responsible for the failings of society. Subsequent attempts to improve social work decision making can be divided into two categories: those that endeavour to de-professionalise social work by creating procedures for social workers to follow and those that endeavour to strengthen professional social work by developing its knowledge and skills base. This book falls into the latter category and is rooted in the belief that the complexity of social situations means that procedures alone cannot determine what social workers do.

There are a number of sources of complexity in social work decision making that require knowledge, analysis and high levels of skill. Social workers need to take into account interacting factors operating on different levels, ranging from the personal to the societal. Each client and his or her situation is unique and when a decision is actually being made it is not possible to predict the outcome with certainty. If social workers could always play it safe, this uncertainty would be less of a problem but the damage and injustice caused would be unacceptable even to social work's fiercest critics. There is also the need to involve clients and other stakeholders in the making of decisions, something made more complicated by them not necessarily sharing the same interests; for example, what is in the interests of carers may not always be in the interest of the people being cared for.

To manage this complexity a professional practice framework is needed rather than bureaucratic procedures and technical rules. The term 'framework' is used to denote a supporting structure of grouped concepts and ideas, placed in relation to each other with the purpose of providing a map that social workers can use to order their minds and act with purpose and clarity in the situations they 


\section{xii Introduction}

face. Such a framework needs to embody the complex features of decision making in social work, such as recognising that social work decision making is not clear cut but involves difficult issues of practice. Decision making is not a single skill but a complex cluster of skills including thinking skills, interpersonal skills and political skills, concerned with processes at micro, intermediate and macro levels. Within the framework the various interacting elements need to be fitted together by taking a holistic perspective requiring a synthesising approach which integrates disparate material from a wide range of subject areas. The resulting synthesis may not always be to the satisfaction of the specialists working in contributory fields of study.

The framework is set out in the nine chapters of this book, with Chapter 1 laying the necessary groundwork by exploring the issues raised by a focus on the making of decisions in social work. Chapter 2 considers the contexts that need to be taken into account when making a decision. The next two chapters focus on the interpersonal and political domains, with Chapter 3 discussing the involvement of clients and Chapter 4 discussing the stakeholders meeting together. Chapter 5 explores the more internal processes of thinking and feeling in decision making. Chapters 6 and 7 look at two central aspects of decision making, framing of the decision situation (Chapter 6) and how the choice of options can be made (Chapter 7). Chapter 8 considers the evaluation of decision making, decision implementation and decision outcome. Finally, Chapter 9 concludes the book by considering why sound decision making does not always lead to good outcomes.

People tend to relate more easily to concrete examples rather than abstract ideas, but abstract ideas are necessary in order to transfer knowledge and skill between different situations. A balance can be achieved by using concrete examples to illustrate abstract ideas so as to facilitate understanding of the issues involved. To this end an illustrative example is used in each chapter, but the reader needs to treat these with caution. The illustrative examples should not be considered as case studies of practice, since they fall far short of giving a full account of the decision making in the situations outlined. They focus on particular points in time and particular decisions, whereas decision making - as stressed above - invariably involves a continuous process of a series of decisions taken over time. While the framework is intended to be a general one applicable across the broad range of social work, in trying to make the 
chapters more accessible, they inevitably have come to reflect the particular concerns of the case examples. The eight case examples do not comprehensively represent the full range of fields and activities to be found within social work. Where specific courses of action have been identified, they have been chosen to illustrate particular points, not examples of good or bad practice.

It also needs to be remembered that the purpose of the following chapters is not to examine the issues of the specific fields of social work, from which the illustrative examples are drawn, but to explore the particular aspect of the decision making framework that forms the subject-matter of that chapter. For example, the purpose of Chapter 1 is not to examine child protection investigations, which happens to be the illustrative example, but to lay the groundwork for building a framework for decision making in social work. In this way the different aspects of decision making in social work are considered chapter by chapter so that by the end of the book the framework of decision making in social work will be complete. Practice issues such as oppression and anti-oppressive practice are integrated throughout the framework as a whole, but the index can be used to identify particular points where more detailed expositions are given. 